\title{
Vasoconstrictor prostanoids
}

${ }^{1}$ Michel Félétou, ${ }^{2}$ Yu Huang $\&{ }^{3}$ Paul M. Vanhoutte

${ }^{1}$ Institut Recherches Servier, Suresnes, France, ${ }^{2}$ Institute of Vascular Medicine, Li Ka Shing Institute of Health Sciences, and School of Biomedical Sciences, Chinese University of Hong Kong, Hong Kong, China, ${ }^{3}$ Department Pharmacology and Pharmacy, Li Ka Shing Faculty Medicine, University of Hong Kong, Hong Kong, China and Department BIN Fusion Technology, Chonbuk National University, Jeonju, Korea. 


\begin{abstract}
In cardiovascular diseases and during ageing, endothelial dysfunction is due in part to the release of endothelium-derived contracting factors (EDCF) that counteract the vasodilator effect of the nitric oxide (NO). Endothelium-dependent contractions involve the activation of endothelial cyclooxygenases and the release of various prostanoids, which activate smooth muscle-thromboxane prostanoid TP receptors of the underlying vascular smooth muscle. The stimulation of TP receptors elicits not only the contraction and the proliferation of vascular smooth muscle cells but also diverse physiological/pathophysiological reactions, including platelet aggregation and activation of endothelial inflammatory responses. TP receptor antagonists curtail endothelial dysfunction in diseases such as hypertension and diabetes, are potent antithrombotic agents and prevent vascular inflammation.
\end{abstract}

Key words: Hypertension, diabetes, aging, endothelium-dependent contraction, TP receptors 
At the very beginning of the endothelial saga, the comparison of the endotheliumdependent responses of canine arteries and veins yielded the surprising finding that in the latter endothelial cells not only release relaxing factors, but also can initiate endotheliumdependent contractions of the underlying vascular smooth muscle cells [13]. A pivotal finding was that those endothelium-dependent contractions can be prevented by various inhibitors of cyclooxygenases [50]. The initial observations made in canine veins were soon extended to the basilar artery of the same species and the aorta of the rat [34,35,43]. Later bioassay studies demonstrated that the endothelium-dependent contractions were indeed caused by vasoconstrictor prostanoids [endothelium-derived contracting factor (EDCF)] produced by the endothelial cells and diffusing to the underlying vascular smooth muscle [90]. The EDCFmediated responses evoked by stretching and agonists that elevate the endothelial intracellular calcium concentration shared the characteristic to be abrogated by inhibitors of cyclooxygenase. Thus, the increase in endothelial intracellular calcium must stimulate phospholipase $A_{2}$, which frees arachidonic acid for further metabolism by cyclooxygenase. The breakdown of the fatty acid by this enzyme generates endothelium-derived constrictor prostanoids. They ultimately activate thromboxane prostanoid (TP) receptors of the smooth muscle to evoke contractions $[5,80]$. Over the years, oxygen derived free radicals $[36,89]$, thromboxane $A_{2}$ [24,68], endoperoxides [21], prostacyclin [23] and prostaglandin $F_{2 \alpha}$ [86] have been identified as cyclooxygenase-derived mediators of endothelium-dependent contractions.

To exemplify this phenomenon, this brief review will highlight the pathological role of endothelium-dependent contractions, especially in aging, hypertension and diabetes, and in view of the central role of cyclooxygenases in these EDCF-mediated responses, will focus 
particularly on the two endothelial isoforms of the enzyme, cyclooxygenase-1 (COX-1) and cyclooxygenase-2 (COX-2).

\section{2) Arachidonic acid metabolism}

Arachidonic acid, the most common precursor of prostaglandins, is generally released from the cell membrane phospholipids by phospholipases and can be metabolized by several enzymatic systems including cyclooxygenases, lipoxygenases and cytochrome P450 monooxygenases [66].

The first cyclooxygenase (COX-1) was purified in 1976 and subsequently cloned in $1988[15,49,51,93]$. In 1991, the product of a second gene (COX-2), possessing also both cyclooxygenase and peroxidase activities, was identified [31,57]. It is generally assumed that COX-1, in most tissues, is expressed constitutively while COX-2 is induced mainly at sites of inflammation $[12,79]$. However, COX-2 is also expressed constitutively in several organs and cell types, including the endothelial cells where its expression is regulated by shear stress (Topper et al., 1996). In the vascular wall, both endothelial and vascular smooth muscle cells contain COXs, however, in healthy blood vessels, endothelial cells contain much more of the enzyme than the surrounding smooth muscle cells [14]. In most blood vessels, prostacyclin, first described as a potent anti-aggregating agent and as a vasodilator, is the principal metabolite of arachidonic acid, the endothelium being the major site of its synthesis [51, Moncada et al., 1977]. In the rat aorta, where both COXs isoforms are detected, the amount of COX-2 transcripts in endothelial or smooth muscle cells is markedly less than that of COX-1 [74]. However, the COX isoform expressed by the human vasculature has been a matter of controversy. Nevertheless, several lines of evidence indicate that in humans, although COX-2 is the predominant contributor of the systemic generation of prostacyclin, endothelial COX-1, in both healthy and diseased blood vessels, appears to be also a major source of vascular 
prostaglandins [McAdam et al., 1999; Funk \& Fitzgerald, 2007; Flavahan, 2007; Rovati et al., 2010].

Various biologically active eicosanoids are formed from the short-lived, but biologically active endoperoxides [prostaglandin $\mathrm{H}_{2}\left(\mathrm{PGH}_{2}\right)$ ], through the action of a set of synthases namely PGD, PGE, PGF, PGI and thromboxane synthases. Prostaglandins interact with specific seven transmembrane, G-protein-coupled receptors, which are classified in five subtypes DP, EP, FP, IP and TP receptors in function of their sensitivity to the five primary prostanoids, prostanglandins $\mathrm{D}_{2}, \mathrm{E}_{2}, \mathrm{~F}_{2 \alpha}, \mathrm{I}_{2}$ (prostacyclin) and thromboxane $\mathrm{A}_{2}$, respectively $[76]$.

The stimulation of TP receptors elicits diverse physiological/pathophysiological responses, including platelet aggregation and smooth muscle contraction. Furthermore, the activation of endothelial TP receptors promotes the expression of adhesion molecules and favours adhesion and infiltration of monocytes/macrophages [56]. Although thromboxane $\mathrm{A}_{2}$ is the preferential physiological ligand of the TP receptor [39], $\mathrm{PGH}_{2}$ and the other prostaglandins, with a various range of potency, also can activate this receptor [23] (Figure 1). Additionally, isoprostanes (prostaglandin isomers that are generally produced nonenzymatically from the oxidative modification of polyunsaturated fatty acids [54] but also in endothelial cells, in a COX-dependent manner [82]) as well as hydroxyeicosatetraenoic acids (HETEs, generated by lipoxygenases and cytochrome P450 monoxygenases or formed by nonenzymatic lipid peroxidation in endothelial cells and leukocytes) are also potent endogenous agonists at TP receptors $[9,19,75,78,92]$.

Prostacyclin is a potent inhibitor of platelet adhesion to the endothelial cell surface and of platelet aggregation [51,59,60] and is generally described as an endothelium-derived vasodilator. Prostacyclin is the preferential ligand of IP receptors and most of its effects involve 
the activation of adenylyl cyclase and the subsequent elevation of intracellular cyclic-AMP $[81,84]$

\section{3) Spontaneously hypertensive rats (SHR): the archetypal model}

The first endothelium-dependent contractions associated with an endothelial dysfunction were observed in the isolated aorta of the SHR [17,43]. In this artery, the endothelium-dependent relaxations are impaired because the generation of a diffusible EDCF opposes the relaxing effect of nitric oxide [43,90]. These endothelium-dependent contractions are correlated with the severity of hypertension. They increase during the aging process and also occur in aging normotensive WKY [32,40]. Endothelium-dependent contractions and the associated endothelial dysfunction are attentated-less pronounced in female SHR [27,37].

Endothelium-dependent responses are associated with an increase in endothelial intracellular calcium concentration $\left(\left[\mathrm{Ca}^{2+}\right]_{\mathrm{i}}\right)$. Indeed, acetylcholine causes a rapid increase in $\left[\mathrm{Ca}^{2+}\right]_{\mathrm{i}}$ in endothelial cells of SHR and to a much lesser extent in that of WKY, while the calcium ionophore A 23187, which allows the free entry of extracellular calcium into endothelial cells, produces a similar increase in $\left[\mathrm{Ca}^{2+}\right]_{\mathrm{i}}$ in the endothelial cells of both WKY and SHR. Acetylcholine- and more generally receptor-mediated endothelium-dependent contractions are larger in SHR than in WKY while the maximal amplitude of these responses, when elicited by A 23187, are similar in the aortae of the two strains [24,73,92]. These results illustrate the first endothelial dysfunction associated with endothelium-dependent contractions, i.e. an abnormal calcium signalling in the endothelial cells of SHR in response to neuro-humoral agents.

Phospholipase $\mathrm{A}_{2}$ catalyzes the breakdown of membrane phospholipids to arachidonic acid. There are two major cytosolic types of the enzyme, calcium-dependent (cPLA $\mathrm{A}_{2}$ and calcium-independent $\left(\mathrm{iPLA}_{2}\right)$ phospholipase $\mathrm{A}_{2}$. The increase in endothelial $\left[\mathrm{Ca}^{2+}\right]_{\mathrm{i}}$, 
irrespective of the stimulus, activates cPLA and provokes the mobilization of arachidonic acid. However, in response to acetylcholine, iPLA $\mathrm{A}_{2}$ is involved by producing lysophospholipids, which open store-operated calcium channels, permitting the influx of extracellular calcium and the subsequent activation of $\mathrm{cPLA}_{2}$. By contrast, the calcium ionophore bypasses the cell membrane receptors and causes increase in endothelial calcium and a direct activation of cPLA 2 (Wong et al., 2010).

The subsequent steps involve the activation of cyclooxygenase and the production of reactive oxygen species along with that of EDCFs and finally the activation of TP receptors $[21,23,24,43,73,89,91]$. In the SHR aorta, COX-1 is the preponderant enzyme involved in the generation of EDCF since endothelium-dependent contractions are blocked by specific inhibitors of COX-1 and minimally affected by specific inhibitors of COX-2 [21,23,24,73,8991]. Indeed, aortic endothelial cells of various species express preferentially COX-1 versus COX-2 $[38,58]$ and, in SHR endothelial cells, the mRNA and protein expression of COX-1 is enhanced when compared to that of WKY [21,74]. In agreement with a preponderant role for COX-1 in endothelium-dependent contractions, these responses are abolished in aortae taken from COX-1 knockout mice while they are maintained in aortic rings of COX-2 knockout animals [72].

However, in both WKY and SHR endothelial cells, the induction of COX-2, especially in resistance arteries and during ageing, is also associated with the generation of endotheliumderived contractile prostanoids. In these arteries, COX-2 contributes to the endothelial dysfunction [2,7,8,20,30,64,81,94, Xavier et al., 2008]. Therefore, the enhanced endothelial expression of COX-1 and/or COX-2 is the second endothelial dysfunction associated with endothelium-dependent contractions.

Additionally, COX is also involved in the endothelial generation of reactive oxygen species. The enhanced COX-dependent generation of reactive oxygen reactive is the third 
endothelial abnormality associated with endothelium-dependent contractions observed in the SHR aorta [73]. Reactive oxygen species decrease NO bioavailability $[28,68]$ and activate COX [29]. This may involve a positive feedback loop on the endothelial cells by further activating COX and, since reactive oxygen species diffuse toward the vascular smooth muscle cells, they can stimulate COX in smooth muscle cells and produce more contractile prostanoids [4,36,89]. Reactive oxygen species can also favour vasethar smooth muscle contraction of the vascular smooth muscle cells. Superoxide anions stimulate $\mathrm{Ca}^{2+}$ release from the sarcoplasmic reticulum of vascular smooth muscle-these cells[67]. In addition, exogenous hydrogen peroxide, - and/or or the reactive oxygen species generated by the activation of TP receptors itself, enhances the stability and increases the density of functional TP receptors at the cell membrane [77, Wilson et al., 2009]. Thus, while the activated TP receptor is being internalized and degraded, a key component in limiting the action of its agonists, a reactive oxygen species-dependent pathway induces the enhanced biogenesis of TP receptor. Activation of this positive feedback mechanism may underlie the augmented TP expression observed in cardiovascular diseases (Katugampola \& Davenport, 2001). Finally, TP receptors are also expressed in endothelial cells and their stimulation can induce the inhibition of NO production [42]. This feed-forward loop involving a reactive oxygen speciesdependent post-transcriptional stabilization of TP receptors associated with a decrease production of NO, further altering the unbalance between relaxing and contracting factors and exacerbating the endothelial dysfunction, suggest that TP receptors are very likely to play a pivotal role in cardiovascular diseases (Wilson et al., 2009).

EDCFs diffuse toward the vascular smooth muscle cells and directly activate the TP receptors [90]. Inhibition of thromboxane $A_{2}$ synthesis does not affect the endotheliumdependent contractions to acetylcholine but partially inhibits those in response to A23187, $\mathrm{ADP}$ or endothelin- $\underline{1}$, indicating that thromboxane $\mathrm{A}_{2}$ is only one of the EDCFs that eould $\underline{\text { can }}$ 
be released from SHR aortic endothelial cells [5,21,23-25,33,41,43,68,89,92]. $\mathrm{PGH}_{2}$ is the second most potent agonist at TP receptors and is more effective in activating TP receptor in vascular smooth muscle from SHR than in that of WKY. Therefore, $\mathrm{PGH}_{2}$ is also a suitable candidate as EDCF [5,21,23-25,33]. However, in SHR aortic endothelial cells, the massive expression of prostacyclin synthase [74] and its close association with COX-1 [38] are not in favour of a large $\mathrm{PGH}_{2}$ spill over. Paradoxically, prostacyclin is likely to be a major EDCF in SHR aorta. Because of an early and specific dysfunction of the smooth muscle-IP-receptors of the vascular smooth muscle [26], prostacyclin does not produce relaxations but evokes TPreceptor-dependent contractions [23,61]. Furthermore, prostacyclin, as $\mathrm{PGH}_{2}$, is also more potent in producing contraction in SHR than in WKY [23]. Therefore, the fourth dysfunction associated with endothelium-dependent contractions involves changes in the responses of the smooth muscle-IP and TP receptors of the vascular smooth muscle without major changes in their respective expression (Numaguchi et al., 1999; 74). Prostacyclin is also a major contributing factor accounting for the endothelial dysfunction in the aorta and mesenteric artery of WKY and SHR treated with aldosterone [7,88]. Finally, $\mathrm{PGE}_{2}$ and $\mathrm{PGF}_{2 \alpha}$ can also act as EDCF when prostacyclin synthase is inhibited and the metabolism of $\mathrm{PGH}_{2}$ diverted [23], a phenomenon that may occur when severe oxidative stress leads to the tyrosine nitration of prostacyclin synthase [96]. Thus, in the SHR aorta, thromboxane $\mathrm{A}_{2}, \mathrm{PGH}_{2}, \mathrm{PGI}_{2}$ and, depending on the circumstances, $\mathrm{PGE}_{2}$ and $\mathrm{PGF}_{2 \alpha}$ can all act as EDCF (Figure 2).

The contribution of EDCF- and TP-receptor-mediated responses in the endothelial dysfunction, first observed in the SHR, has been reported in numerous other models of hypertension and is likely to occur in patients with essential hypertension [18]. Additionally, non-endothelium-derived contractile prostanoids can contribute to vascular dysfunction. For instance, in the aorta of the hypertensive eNOS knockout mice, smooth muscle- and COX-2- 
derived thromboxane $A_{2}$ contributes to the enhanced contractions in response to endothelin-1 [95].

\section{4) Enhanced action of COX-derived EDCF in ageing}

Aging favours a shift of the fine balance between NO-mediated endothelium-dependent relaxations and COX-dependent contractions towards the latter. Impaired endotheliumdependent relaxations to acetylcholine have been demonstrated in the aorta and superior mesenteric arteries of aged rats. This is, accompanied by an increased expression of COX isoforms. The relaxations are potentiated by a non-selective COX inhibitor indomethacin, suggesting a critical role of COX-derived vasoconstrictor prostanoids in impairing endothelium-dependent relaxations [46]. Similar findings are reported in small mesenteric arteries [1], in which indomethacin and a specific COX-2 inhibitor NS-398, restored the attenuated endothelium-dependent relaxations and eliminated contractions caused by high concentrations of acetylcholine.

Endothelium-dependent contractions are usually unveiled in pathological models, owing to a reduction of NO bioavailability that allows the emergence of endothelium-dependent contractions. However, there are exceptions, one being the occurrence of endotheliumdependent contractions in the aorta of young and healthy hamsters $[85,86]$. In this preparation, COX-2 is expressed constitutively and incubation with an inhibitor of eNOS unmasks the ability of acetylcholine to elicit endothelium-dependent contractions which are sensitive to COX-2 inhibition and TP receptor antagonism, while these responses are unaffected by COX1 inhibitors and reactive oxygen species scavengers. By contrast to the SHR aorta in which the proposed EDCFs are prostacyclin, $\mathrm{PGH}_{2}$ and thromboxane $\mathrm{A}_{2}$, the endothelium-derived vasoconstrictor prostanoid responsible in the hamster aorta appears to be $\mathrm{PGF}_{2 \alpha}[85,86]$. In the hamster, aging not only exaggerates endothelium-dependent contractions, which are again 
attenuated by COX-2 inhibitors, but also increases COX-2 expression and augments the release of and the vascular sensitivity to $\mathrm{PGF}_{2 \alpha}$ [86]. One distinctive feature of the endothelium-dependent contraction in the aorta of aged hamsters compared with their younger counterparts is that the response can be observed in the absence of inhibitors of eNOS. On the other hand, the endothelium-dependent relaxations are diminished in preparations from aging hamsters, reinforcing the interpretation that endothelium-dependent contractions are unmasked by a reduction in NO bioavailability in aged animals.

The alterations in the endothelial function observed in various animal models of aging suggest that the endothelial dysfunction observed in hypertension could $\underline{\text { can }}$ be considered as a consequence of the premature aging of the vessel wall [17].

\section{5) Role of prostanoids in endothelial dysfunction in diabetes}

Micro- and macrovascular diseases are currently the major causes of morbidity and mortality in patients with diabetes mellitus and endothelial dysfunction plays also a key role in the pathogenesis of these diabetic vascular diseases. Impaired endothelium-dependent vasodilatation has been demonstrated in various vascular beds of different animal models of diabetes and in humans with type 1 and 2 diabetes. However, the mechanisms of endothelial dysfunction appear to differ according to the diabetic model and the vascular bed under study and include impaired signal transduction or substrate availability, impaired release of NO, increased destruction of NO, decreased sensitivity of the vascular smooth muscle to NO and enhanced release of endothelium-derived constricting factors. These dysfunctions are again generally associated with the over-generation of reactive oxygen species, lipid peroxidation, and elevated production of adhesion molecules [47, De Vriese et al., 2000].

Streptozotocin-induced diabetes leads to a diminished endothelium-dependent NOmediated relaxation in rat conduit arteries. and-TP receptor antagonism, again, restores the impaired relaxation and prevents the endothelium-dependent contraction. Neither 
thromboxane $A_{2}$ nor prostacyclin plays a significant role as the relaxation is unaffected by thromboxane $\mathrm{A}_{2}$ synthesis inhibition and since prostacyclin does not cause contractions in those arteries [65]. Likewise, indomethacin inhibits the occurrence of endothelium-dependent contractions in the femoral artery of streptozotocin-treated rats and-whereby COX-1-derived products appear to play a dominant role [63]. Thromboxane $A_{2}$ does not play a direct role in reducing endothelial function in type 1 diabetes, but endothelium-derived thromboxane $A_{2}$ may be involved in the enhanced contractile response to endothelin- 1 as thromboxane $A_{2}$ synthesis inhibition attenuates the exaggerated contraction to endothelin-1 in the mesenteric arteries of streptozotocin-treated rats [3]. In the mesenteric artery of type 2 diabetic OLETF rats, the impaired endothelium-dependent relaxation to acetylcholine is normalized and the contraction to the muscarinic agonist inhibited by indomethacin [45]. The acetylcholinestimulated release of thromboxane $\mathrm{A}_{2}$ and $\mathrm{PGE}_{2}$ are greater in OLETF than non-diabetic rats; however, this study did not further determine whichbut it is not clear which -COX-derived prostanoid is most likely involved [45?]. The impaired endothelium-dependent relaxations in the mesenteric vascular bed of streptozotocin-induced diabetic mice is opposed by a compensatory up-regulation of both expression and activity of COX-2 and selective inhibition of COX-2 unmasks endothelial dysfunction [55], suggesting a vascular benefit of COX-2derived products. 
Despite a clearly demonstrated role of COX-derived prostaglandins in the regulation of vascular reactivity in conduit arteries, their link to endothelium-dependent hyperpolarization of vascular smooth muscle (EDHF-mediated responses) in resistance blood vessels is unclear. Indomethacin augments the endothelium-dependent EDHF-mediated relaxation in mesenteric resistance arteries from streptozotocin-induced diabetic but not in those from control mice [53], suggesting that COX-derived prostanoids inhibit either the release of EDHF from the endothelium or its action on vascular smooth muscle [53].

\section{6) Clinical relevance}

The information available in animal models demonstrates that in aging and in a number of diseases such as hypertension, diabetes and atherosclerosis, as the endothelium becomes dysfunctional, the release of EDCF is favoured and endothelium-dependent contractions become more prominent $[11,22,41,43,45]$. The indirect evidence available in people suggests that the same is true. Indeed, indomethacin potentiates the relaxations to acetylcholine in isolated renal arteries of aged patients [44] and the vasodilator response to the muscarinic agonist in the forearm of people with essential hypertension [69-71]. The comparison of the effect of the non-selective inhibitor of cyclooxygenases in different age groups further suggests that the contribution EDCF augments with advancing age [70,71], as it does in the animal. In patients with endothelial dysfunction an improvement was observed with selective COX-2 inhibitors [10,83], which may imply an important role for that isoform of the enzyme. The TP-receptor blocker S18886 improves endothelial function in patients with coronary disease [6], which further illustrates the role of vasoconstrictor prostanoids in human endothelial dysfunction.

The role of the specific COX isoforms and arachidonic acid metabolites in the regulation of vascular function in human diabetes is less well defined. In young patients with 
type 1 diabetes, the impaired NO-dependent relaxation might-may be compensated by an increase in prostacyclin-mediated responses [48]. Indeed, indomethacin-sensitive blood flow is greater in patients with type 1 diabetes than in non-diabetic subjects [87], further suggesting a compensatory response for prostacyclin when the bioavailability of NO is declining. On the other hand, COX-derived prostanoids contribute to the appearance of endothelium-dependent contractions in arteries from older patients with diabetes and hypertension [86].

Since the stimulation of TP receptors elicits not only the contraction and the proliferation of vascular smooth muscle cells but also diverse physiological/pathophysiological reactions in platelets (adhesion and aggregation), and endothelial cells (expression of adhesion molecules associated with the subsequent adhesion and infiltration of monocytes/macrophages)_Refs???, TP receptor antagonists may have a Formatted: Font: Bold unique potential for the treatment of cardiovascular disorders (Figure 3). However, in contrast to many examples of animal models of cardiovascular diseases, in patients, no study is yet available demonstrating that reversal of endothelial dysfunction is independently associated with a better clinical outcome. The results of large-scale clinical trials are awaited in order to determine the proper therapeutic indication of TP antagonists and to confirm their potential beneficial effect. 


\section{7) References}

1 Alvarez de Sotomayor M, Mingorance C, Andriantsitohaina R. (2007) Fenofibrate improves age-related endothelial dysfunction in rat resistance arteries. Atherosclerosis. 193:112-120.

2 Alvarez Y, Briones AM, Balfagón G, Alonso MJ, Salaices M. (2005) Hypertension increases the participation of vasoconstrictor prostanoids from cyclooxygenase-2 in phenylephrine responses. J Hypertens. 23:767-77.

3 Arikawa E, Cheung C, Sekirov I, Battell ML, Yuen VG, McNeill JH. (2006) Effects of endothelin receptor blockade on hypervasoreactivity in streptozotocin-diabetic rats: vesselspecific involvement of thromboxane $A_{2}$. Can J Physiol Pharmacol. 84:823-833.

4 Auch-Schwelk W, Katusic ZS, Vanhoutte PM (1989) Contractions to oxygen-derived free radicals are augmented in aorta of the spontaneously hypertensive rat. Hypertension 13:859-864.

5 Auch-Schwelk W, Katusic ZS, Vanhoutte PM. (1990) Thromboxane A2 receptor antagonists inhibit endothelium-dependent contractions. Hypertension 15:699-703.

6 Belhassen L, Pelle G, Dubois-Rande J, Adnot S (2003). Improved endothelial function by the thromboxane $\mathrm{a}_{2}$ receptor antagonist $\mathrm{s} 18886$ in patients with coronary artery disease treated with aspirin. J Am Coll Cardiol 41:1198-1204.

7 Blanco-Rivero J, Cachofeiro V, Lahera V, Aras-Lopez R, Márquez-Rodas I, Salaices M, Xavier FE, Ferrer M, Balfagón G. (2005) Participation of prostacyclin in endothelial dysfunction induced by aldosterone in normotensive and hypertensive rats. Hypertension. 46:107-112.

8 Camacho M, Lopez-Belmonte J, Vila L. (1998) Rate of vasoconstrictor prostanoids released by endothelial cells depends on cyclooxygenase-2 expression and prostaglandin I synthase activity. Circ Res. 83:353-65. 
The thromboxane receptor antagonist S18886 but not aspirin inhibits atherogenesis in apo Edeficient mice: evidence that eicosanoids other than thromboxane contribute to atherosclerosis. Arterioscler Thromb Vasc Biol. 20:1724-1728.

10 Chenevard R, Hürlimann D, Béchir M, Enseleit F, Spieker L, Hermann M, Riesen W, Gay S, Gay RE , Neidhart M, Michel B, Lüscher TF, Noll G, Ruschitzka F (2003) Selective COX-2 inhibition improves endothelial function in coronary artery disease. Circulation 107:405-409.

11 Cohen RA. (2002) Does EDCF contribute to diabetic endothelial cell dysfunction? Dialog Cardiovasc Med 7:225-231.

12 Davidge ST (2001) Prostaglandin H synthase and vascular function. Circ Res 89:650660.

13 De Mey JG, Vanhoutte PM. (1982) Heterogeneous behavior of the canine arterial and venous wall. Importance of the endothelium. Circ Res 51:439-447.

14 De Witt DL, Day JS, Sonnenburg WK, Smith WL (1983) Concentrations of prostaglandin endoperoxide synthase and prostaglandin I2 synthase in the endothelium and smooth muscle of bovine aorta. J Clin Invest 72:1882-1888.

15 De Witt DL, Smith WL (1988) Primary structure of prostaglandin G/H synthase from sheep vesicular gland determined from the complementary DNA sequence. Proc Natl Acad Sci USA 85:1412-1416.

16 Doroudi R, Gan LM, Selin Sjogren L, Jern S (2000) Effects of shear stress on eicosanoid gene expression and metabolites production in vascular endothelial cells as studied in a novel biomechanical perfusion model. Biochem Biophys Res Comm 269:257-264.

17 Félétou M, Vanhoutte PM. (2006) Endothelial dysfunction: a multifaceted disorder (The Wiggers Award Lecture). Am J Physiol Heart Circ Physiol. 291:H985-1002. 
Félétou M, Vanhoutte PM, Verbeuren TJ (2010) The TP-receptor: the common villain. J Cardiovasc Pharmacol (in press).

19 Fonlupt P, Croset M, Lagarde M. (1991) 12-HETE inhibits the binding of PGH2/TXA2 receptor ligands in human platelets. Thromb Res. 63:239-248.

20 Garcia-Cohen EC, Marin J, Diez-Picazo LD, Baena AB, Salaices M, RodriguezMartinez MA. (2000) Oxidative stress induced by tert-butyl hydroperoxide causes vasoconstriction in the aorta from hypertensive and aged rats: role of cyclooxygenase-2 isoform. J Pharmacol Exp Ther. 293:75-81.

21 Ge T, Hughes H, Junquero DC, Wu KK, Vanhoutte PM, Boulanger CM (1995) Endothelium dependent contractions are associated with both augmented expression of prostaglandin $\mathrm{H}$ synthase-1 and hypersensitivity to prostaglandin $\mathrm{H}_{2}$ in the SHR aorta. Circ Res 76:1003-1010.

22 Gendron ME, Thorin E (2007) A change in the redox environment and thromboxane A2 production precede endothelial dysfunction in mice. Am J Physiol Heart Circ Physiol 293:H2508-2515.

23 Gluais P, Lonchampt M, Morrow JD, Vanhoutte PM, Félétou M (2005) Acetylcholine-induced endothelium-dependent contractions in the SHR aorta: the Janus face of prostacyclin. Br J Pharmacol. 146:834-845.

24 Gluais P, Paysant J, Badier-Commander C, Verbeuren T, Vanhoutte PM, Félétou M. (2006) In SHR aorta, calcium ionophore A-23187 releases prostacyclin and thromboxane A2 as endothelium-derived contracting factors. Am J Physiol Heart Circ Physiol. 291:H22552564.

25 Gluais P, Vanhoutte PM, Félétou M. (2007) Mechanisms underlying ATP-induced endothelium-dependent contractions in the SHR aorta. Eur J Pharmacol. 556:107-114. 
TJ, Félétou M. (2008) Aging and prostacyclin responses in aorta and platelets from WKY and SHR rats. Am J Physiol Heart Circ Physiol. 295:H2198-2211.

27 Graham DA, Rush JW. (2009) Cyclooxygenase and thromboxane/prostaglandin receptor contribute to aortic endothelium-dependent dysfunction in aging female spontaneously hypertensive rats. J Appl Physiol. 2009 [Epub ahead of print].

28 Gryglewski RJ, Palmer RM, Moncada S. (1986) Superoxide anion is involved in the breakdown of endothelium-derived vascular relaxing factor. Nature 320:454-456.

29 Harlan JM, Callahan KS. (1984) Role of hydrogen peroxide in the neutrophilmediated release of prostacyclin from cultured endothelial cells. J Clin Invest. 74:442-8.

30 Heymes C, Habib A, Yang D, Mathieu E, Marotte F, Samuel JL, Boulanger CM. (2000) Cyclo-oxygenase-1 and -2 contribution to endothelial dysfunction in ageing. Br J Pharmacol 131:804-810.

31 Hla T, Neilson K (1992) Human cyclooxygenase-2 cDNA. Proc. Natl. Acad. Sci. USA. 89:7384-7388.

32 Iwama Y, Kato T, Muramatsu M, Asano H, Shimizu K, Toki Y, Miyazaki Y, Okumura K, Hashimoto H, Ito T, Satake T. (1992) Correlation with blood pressure of the acetylcholine-induced endothelium-derived contracting factor in the rat aorta. Hypertension, 19:326-332.

33 Kato T, Iwama Y, Okumura K, Hashimoto H, Ito T, Satake T. (1990) Prostaglandin $\mathrm{H} 2$ may be the endothelium-derived contracting factor released by acetylcholine in the aorta of the rat. Hypertension. 15:475-481.

34 Katusic Z, Shepherd JT, Vanhoutte PM (1987) Endothelium-dependent contraction to stretch in canine basilar arteries. Am J Physiol 21:H671-H673. 
to calcium ionophore A23187, arachidonic acid and acetylcholine in canine basilar arteries. Stroke 19:476-479.

36 Katusic ZS, Vanhoutte PM (1989) Superoxide anion is an endothelium-derived contracting factor. Am J Physiol. 257:H33-37.

37 Kauser K, Rubanyi GM. (1995) Gender difference in endothelial dysfunction in the aorta of spontaneously hypertensive rats. Hypertension. 25:517-523.

38 Kawka DW, Ouellet M, Hétu PO, Singer II, Riendeau D. (2007) Double-label expression studies of prostacyclin synthase, thromboxane synthase and COX isoforms in normal aortic endothelium. Biochim Biophys Acta. 1771:45-54.

39 Kiriyama M, Ushikubi F, Kobayashi T, Hirata M, Sugimoto Y, Narumiya S. (1997)

Ligand binding specificities of the eight types and subtypes of the mouse prostanoid receptors expressed in Chinese hamster ovary cells. Br J Pharmacol. 122:217-224.

40 Koga T, Takata Y, Kobayashi K, Takeshita S, Yamashita Y, Fujishima M. (1988) Ageing suppresses endothelium-dependent relaxation and generates contraction mediated by the muscarinic receptors in vascular smooth muscle of normotensive Wistar Kyoto and spontaneously hypertensive rats. J Hypertens. 6:S243-S245.

41 Koga T, Takata Y, Kobayashi K, Takishita S, Yamashita Y, Fujishima M. (1989) Age and hypertension promote endothelium-dependent contractions to acetylcholine in the aorta of the rat. Hypertension 14:542-548.

42 Liu CQ, Leung FP, Wong SL, Wong WT, Lau CW, Lu L, Yao X, Yao T, Huang Y. (2009) Thromboxane prostanoid receptor activation impairs endothelial nitric oxidedependent vasorelaxations: the role of Rho kinase. Biochem Pharmacol. 78:374-381.

43 Lüscher TF, Vanhoutte PM (1986) Endothelium-dependent contractions to acetylcholine in the aorta of the spontaneously hypertensive rat. Hypertension 8:344-348. 

dependent relaxations in human arteries. Mayo Clin Proc. 62:601-606.

45 Matsumoto T, Kakami M, Noguchi E, Kobayashi T, Kamata K. (2007) Imbalance between endothelium-derived relaxing and contracting factors in mesenteric arteries from aged OLETF rats, a model of Type 2 diabetes. Am J Physiol Heart Circ Physiol. 293:H14801490.

46 Matz RL, de Sotomayor MA, Schott C, Stoclet JC, Andriantsitohaina R. (2000) Vascular bed heterogeneity in age-related endothelial dysfunction with respect to NO and eicosanoids. Br J Pharmacol. 131:303-311.

47 Mazzone T, Chait A, Plutzky J. (2008) Cardiovascular disease risk in type 2 diabetes mellitus: insights from mechanistic studies. Lancet. 371:1800-1809.

48 Meeking D, Browne D, Allard S, Munday J, Chowienczyk P, Shaw KM, Cummings MH. (2000) Effects of cyclo-oxygenase inhibition on vasodilatory response to acetylcholine in patients with type 1 diabetes and nondiabetic Diabetes Care 23:1-4.

49 Merlie JP, Fagan D, Mudd J, Needleman P (1988) Isolation and characterization of the complementary DNA for sheep seminal prostaglandins endoperoxide synthase (cyclooxygenase). J Biol Chem 263:3550-3553.

50 Miller VM, Vanhoutte PM (1985) Endothelium-dependent contractions to arachidonic acid are mediated by products of cyclo-oxygenase in canine veins. Am J Physiol 248:H432H437.

51 Moncada S, Gryglewski RJ, Bunting S, Vane JR (1976) An enzyme isolated from arteries transforms prostaglandin endoperoxides to an unstable substance that inhibits platelet aggregation. Nature 263:663-665.

52 Moncada S, Vane JR (1979) Pharmacology and endogenous roles of prostaglandin endoperoxides, thromboxane A2 and prostacyclin. Pharmacol Rev 30:293-331. 
Shimokawa H. (2005) Influence of diabetes mellitus, hypercholesterolemia, and their combination on EDHF-mediated responses in mice. J Cardiovasc Pharmacol. 45:485-90.

54 Morrow JD, Hill KE, Burk RF, Nannour TM, Badr KF, Roberts II LJ. (1990) A series of prostaglandins F2-like compounds are produced in vivo in humans by a noncyclooxygenase, free radical catalysed mechanism. Proc Natl Acad Sci USA 87:9383-9387.

55 Nacci C, Tarquinio M, De Benedictis L, Mauro A, Zigrino A, Carratù MR, Quon MJ, Montagnani M. (2009) Endothelial dysfunction in mice with streptozotocin-induced type 1 diabetes is opposed by compensatory overexpression of cyclooxygenase- 2 in the vasculature. Endocrinology. 150:849-61.

56 Nakahata N. (2008) Thromboxane A2: Physiology/pathophysiology, cellular signal transduction and pharmacology. Pharmacol \& Therapeut. 118:18-35.

57 O’Banion MK, Winn VD, Young DA (1992) cDNA cloning and functional activity of a glucocorticoid-regulated inflammatory cyclooxygenase. Proc Natl Acad Sci USA 89:48884892.

58 Onodera M, Morita I, Mano Y, Murota S. (2000) Differential effects of nitric oxide on the activity of prostaglandin endoperoxide $\mathrm{H}$ synthase-1 and -2 in vascular endothelial cells. Prostaglandins Leukot Essent Fatty Acids. 62:161-167.

59 Radomski MW, Palmer RMJ, Moncada S (1987a) Comparative pharmacology of endothelium-derived relaxing factor, nitric oxide and prostacyclin in platelets. Br J Pharmacol 92:181-187.

60 Radomski MW, Palmer RMJ, Moncada S (1987b) The anti-aggregating properties of vascular endothelium: interactions between prostacyclin and nitric oxide. Br J Pharmacol 92:639-646. 

contraction of aorta from spontaneously hypertensive and Wistar-Kyoto rats. Hypertension 28:64-75.

62 Rubanyi GM, Vanhoutte PM (1986) Superoxide anions and hyperoxia inactivate endothelium-derived relaxing factor. Am J Physiol 250:H222-H227.

63 Shi Y, Feletou M, Ku DD, Man RYK, Vanhoutte PM. (2007) The calcium ionophore A23187 induces endothelium-dependent contractions in femoral arteries from rats with streptozotocin-induced diabetes. Br J Pharmacol. 150:624-632.

64 Shi Y, Man RY, Vanhoutte PM (2008) Two isoforms of cyclooxygenase contribute to augmented endothelium-dependent contractions in femoral arteries of 1-year-old rats. Acta Pharmacol Sin. 29:185-192.

65 Shimizu K, Muramatsu M, Kakegawa Y, Asano H, Toki Y, Miyazaki Y, Okumura K, Hashimoto H, Ito T. (1993) Role of prostaglandin $\mathrm{H}_{2}$ as an endothelium-derived contracting factor in diabetic state. Diabetes. 42:1246-52.

66 Smith WL, Marnett LJ (1991) Prostaglandin endoperoxide synthase: structure and catalysis. Biochem Biophys Acta 1083:1-17.

67 Suzuki YJ, Ford GD. (1992) Superoxide stimulates IP3-induced $\mathrm{Ca}^{2+}$ release from vascular smooth muscle sarcoplasmic reticulum. Am J Physiol. 262:H114-116.

68 Taddei S, Vanhoutte PM. (1993) Role of endothelium in endothelin-evoked contractions in the rat aorta. Hypertension. 21:9-15.

69 Taddei S, Virdis A, Ghiadoni L, Magagna A, Salvetti A (1997). Cyclooxygenase inhibition restores nitric oxide activity in essential hypertension. Hypertension 29:274-279.

70 Taddei S, Virdis A, Mattei P, Ghiadoni L, Fasolo CB, Sudano I, Salvetti A (1997). Hypertension causes premature aging of endothelial function in humans. Hypertension 29:736-743. 

(1995). Aging and endothelial function in normotensive subjects and patients with essential hypertension. Circulation 91:1981-1987.

72 Tang EH, Ku DD, Tipoe GL, Félétou M, Man RY, Vanhoutte PM. (2005) Endothelium-dependent contractions occur in the aorta of wild-type and COX2-/- knockout but not COX1-/- knockout mice. J Cardiovasc Pharmacol. 46:761-765.

73 Tang EH, Leung FP, Huang Y, Félétou M, So KF, Man RY, Vanhoutte PM. (2007) Calcium and reactive oxygen species increase in endothelial cells in response to releasers of endothelium-derived contracting factor. Br J Pharmacol. 151:15-23.

74 Tang EH, Vanhoutte PM. (2008) Gene expression changes of prostanoid synthases in endothelial cells and prostanoid receptors in vascular smooth muscle cells caused by aging and hypertension. Physiol Genomics 32:409-418.

75 Tesfamariam B, Brown ML, Cohen RA. (1995) 15-Hydroxyeicosatetraenoic acid and diabetic endothelial dysfunction in rabbit aorta. J Cardiovasc Pharmacol 25:748-755.

76 Tsuboi K, Sugimoto Y, Ichikawa A (2002) Prostanoid receptor subtypes. Prostaglandins Other Lipid Mediat. 68-69:535-556.

77 Valentin F, Field MC, Tippins JR. (2004) The mechanism of oxidative stress stabilization of the thromboxane receptor in COS-7 cells. J Biol Chem. 279:8316-8324.

78 Van Diest MJ, Verbeuren TJ, Herman AG. (1991) 15-lipoxygenase metabolites of arachidonic acid evoke contractions and relaxations in isolated canine arteries: role of thromboxane receptors, endothelial cells and cyclooxygenase. J Pharmacol Exp Ther. 256:194-203.

79 Vane J, Bakhle YS, Botting RM (1998) Cyclooxygenases 1 and 2. Annu Rev Pharmacol Toxicol 38:97-120. 

hypertension. Br J Pharmacol. 144:449-458.

81 Virdis A, Colucci R, Versari D, Ghisu N, Fornai M, Antonioli L, Duranti E, Daghini E, Giannarelli C, Blandizzi C, Taddei S, Del Tacca M. (2009) Atorvastatin prevents endothelial dysfunction in mesenteric arteries from spontaneously hypertensive rats: role of cyclooxygenase 2-derived contracting prostanoids. Hypertension. 53:1008-1016.

82 Watkins MT, Patton GM, Soler HM, Albadawi H, Humphries DE, Evans JE, Kadowaki K (1999) Synthesis of 8-epi-prostaglandinF2 $\alpha$ by human endothelial cells: role of prostaglandin H2 synthase. Biochem J 344:747-775.

83 Widlansky ME, Price DT, Gokce N, Eberhardt RT, Duffy SJ, Holbrook M, Maxwell C, Palmisano J, Keaney JF Jr, Morrow JD, Vita JA (2003) Short- and long- term COX-2 inhibition reverses endothelial dysfunction in patients with hypertension. Hypertension 42:310-315, 2003.

84 Wise H, Jones RL (1996) Focus on prostacyclin and its novel mimetics. Trends Pharmacol Sci 17:17-21.

85 Wong SL, Leung FP, Lau CW, Vanhoutte P, Huang Y. (2008) Endothelium-dependent contractions in hamster aorta: The essential role of COX-2 and prostaglandin-2 $\alpha$. Basic Clin Pharmacol Toxicol. 102 (Suppl. 1):15-15.

86 Wong SL, Leung FP, Lau CW, Au CL, Yung LM, Yao X, Chen ZY, Vanhoutte PM, Gollasch M, Huang Y. (2009) Cyclooxygenase-2-derived prostaglandin F2alpha mediates endothelium-dependent contractions in the aortae of hamsters with increased impact during aging. Circ Res. 104:228-235.

87 Wotherspoon F, Browne DL, Meeking DR, Allard SE, Munday LJ, Shaw KM, Cummings MH. (2005) The contribution of nitric oxide and vasodilatory prostanoids to bradykinin-mediated vasodilation in Type 1 diabetes. Diabet Med. 22:697-702. 
M, Balfagón G (2008) Aldosterone induces endothelial dysfunction in resistance arteries from normotensive and hypertensive rats by increasing thromboxane A2 and prostacyclin. $\mathrm{Br} \mathrm{J}$ Pharmacol. 154:1225-1235.

89 Yang D, Félétou M, Boulanger CM, Wu HF, Levens N, Zhang JN, Vanhoutte PM. (2002) Oxygen-derived free radicals mediate endothelium-dependent contractions to acetylcholine in aortas from spontaneously hypertensive rats. Br J Pharmacol. 136:104-110.

90 Yang D, Félétou M, Levens N, Zhang JN, Vanhoutte PM (2003a) A diffusible substance(s) mediates endothelium-dependent contractions in the aorta of SHR. Hypertension 41:143-148. 91 Yang D, Levens N, Zhang JN, Vanhoutte PM, Félétou M (2003b) Specific potentiation of endothelium-dependent contractions in SHR by tetrahydrobiopterin. Hypertension. 41:136-42. 92 Yang D, Gluais P, Zhang JN, Vanhoutte PM, Félétou M. (2004) Endothelium-dependent contractions to acetylcholine, ATP and the calcium ionophore A 23187 in aortas from spontaneously hypertensive and normotensive rats. Fundam Clin Pharmacol 18:321-326.

93 Yokohama C, Takai T, Tanabe T (1988) Primary structure of sheep prostaglandin endoperoxide synthase deduced from cDNA sequence. FEBS Lett. 231:347-351.

94 Zerrouk A, Auguet M, Chabrier PE. (1998) Augmented endothelium-dependent contraction to angiotensin II in the SHR aorta: role of an inducible cyclooxygenase metabolite. J Cardiovasc Pharmacol. 31:525-33.

95 Zhou Y, Mitra S, Varadharaj S, Parinandi N, Zweier JL, Flavahan NA. (2006) Increased expression of cyclooxygenase-2 mediates enhanced contraction to endothelin ETA receptor stimulation in endothelial nitric oxide synthase knockout mice. Circ Res. 98:1439-1445.

96 Zou MH, Shi C, Cohen RA. High glucose via peroxynitrite causes tyrosine nitration and inactivation of prostacyclin synthase that is associated with thromboxane/prostaglandin $\mathrm{H}(2)$ 
receptor-mediated apoptosis and adhesion molecule expression in cultured human aortic endothelial cells. Diabetes. 2002;51:198-203.

Wong MS, Man RY, Vanhoutte PM. Calcium-independent phospholipase A2 plays a key role in the endothelium-dependent contractions to acetylcholine in the aorta of SHR. Am J Physiol Heart Circ Physiol. 2010;[Epub ahead of print]

Xavier FE, Aras-López R, Arroyo-Villa I, Campo LD, Salaices M, Rossoni LV, Ferrer M, Balfagón G. Aldosterone induces endothelial dysfunction in resistance arteries from normotensive and hypertensive rats by increasing thromboxane A2 and prostacyclin. $\mathrm{Br} J$ Pharmacol. 2008;154(6):1225-1235.

Wilson SJ, Cavanagh CC, Lesher AM, Frey AJ, Russell SE, Smyth EM. Activationdependent stabilization of the human thromboxane receptor: role of reactive oxygen species. $J$ Lipid Res. 2009;50:1047-1056.

Katugampola SD, Davenport AP. Thromboxane receptor density is increased in human cardiovascular disease with evidence for inhibition at therapeutic concentrations by the AT(1) receptor antagonist losartan. Br J Pharmacol. 2001;134(7):1385-92

Topper JN, Cai J, Falb D, Gimbrone MA Jr. Identification of vascular endothelial genes differentially responsive to fluid mechanical stimuli: cyclooxygenase-2, manganese superoxide dismutase, and endothelial cell nitric oxide synthase are selectively up-regulated by steady laminar shear stress. Proc Natl Acad Sci U S A. 1996; 93:10417-10422.

Moncada S, Herman AG, Higgs EA, Vane JR. (1977) Differential formation of prostacyclin (PGX or $\mathrm{PGI}_{2}$ ) by layers of the arterial wall. An explanation for the anti-thrombotic properties of vascular endothelium. Thromb. Res. 1977;11: 323-344.

McAdam BF, Catella-Lawson F, Mardini IA, Kapoor S, Lawson JA, FitzGerald GA. Systemic biosynthesis of prostacyclin by cyclooxygenase (COX)-2: the human pharmacology of a selective inhibitor of COX-2. Proc Natl Acad Sci U S A. 1999;96:272-277. 
Funk CD, FitzGerald GA. COX-2 inhibitors and cardiovascular risk. J Cardiovasc Pharmacol. 2007;50:470-479.

Flavahan NA. Balancing prostanoid activity in the human vascular system. Trends Pharmacol Sci. 2007;28: 106-110.

Rovati GE, Sala, A, Capra V, Dahlen SE, Folco G. Dual COXIB/TP antagonists: a possible new twist in NASID pharmacology and cardiovascular risk. Trends Pharmacol Sci 2010, epub ahead of print.

De Vriese AS, Verbeuren TJ, Van de Voorde J, Lameire NH, Vanhoutte PM. Endothelial dysfunction in diabetes. Br J Pharmacol. 2000;130(5):963-74.

Numaguchi, Y., Harada, M., Osanai, H., Hayashi, K., Toki, Y., Okamura, K., Ito, T. \& Hayakawa, T. (1999) Altered gene expression of prostacyclin synthase and prostacyclin receptor in the thoracic aorta of spontaneously hypertensive rats. Cardiovasc Res. 41, 682688. 
Figure Legends

\section{Figure 1 Endothelium-dependent responses in WKY and SHR isolated aortic rings}

The isometric-measurement of the changes in isometric tension in isolated aortic rings contracted with phenylephrine (PE) shows that the acetylcholine-induced endotheliumdependent relaxation is blunted in SHR rings when compared to that of normotensive WKY. In SHR quiescent rings treated with an inhibitor of NO synthase (L-nitroarginine: L-NA), acetylcholine produces endothelium- and concentration-dependent contractions, which are blocked by valeryl salicylate, a preferential COX-1 inhibitor or S 18886 a specific TP receptor antagonist, but are only partially inhibited by NS-398, a preferential COX-2 inhibitor. Source?

Figure 2 Mechanisms of endothelium-dependent contractions in WKY and SHR aortic rings

M: muscarinic receptor, AA: arachidonic acid, eNOS: endothelial nitric oxide synthase, NO: nitric oxide, $\mathrm{O}_{2}^{-}$: superoxide anion, PGS: prostaglandin synthases, COX-1: cyclooxygenase-1, $\mathrm{PGI}_{2}$ : prostacyclin, $\mathrm{TXA}_{2}$ : thromboxane $\mathrm{A}_{2}$, TP: TP receptor, IP: IP receptor, SR: sarcoplasmic reticulum, Sol GC: soluble guanylyl cyclase, GTP: guanosine triphosphate, cGMP: cyclic guanosine monophosphate. The number (1), (2), (3) and (4) indicates identified abnormalities which contribute to the exacerbated endothelium-dependent contractions in SHR aorta, i.e. endothelial calcium handling, enhanced endothelial COX-1 expression and activity, increased generation of endothelial reactive oxygen species and dysfunctional smooth muscle TP and IP receptors, respectively. Modified from? 


\section{Figure 3 Involvement of TP and IP receptors in vascular dysfunction}

COXs: cyclooxygenases, LOX: lipoxygenase, P450: cytochrome P450 monooxygenase, ROS: reactive oxygen species, PGS: prostaglandin synthases, PGIS: prostacyclin synthase, TXS thromboxane synthase, PGs: prostaglandins, $\mathrm{PGG}_{2}$ : prostaglandin $\mathrm{G}_{2}, \mathrm{PGH}_{2}$ : prostaglandin $\mathrm{H}_{2}, \quad \mathrm{PGI}_{2}$ : prostaglandin $\mathrm{I}_{2}$ (prostacyclin), $\mathrm{TXA}_{2}$ : thromboxane $\mathrm{A}_{2}$, HETE: hydroxyeicosatetraenoic acid 
Figure 1

Endothelium-dependent responses in WKY and SHR isolated aortic rings

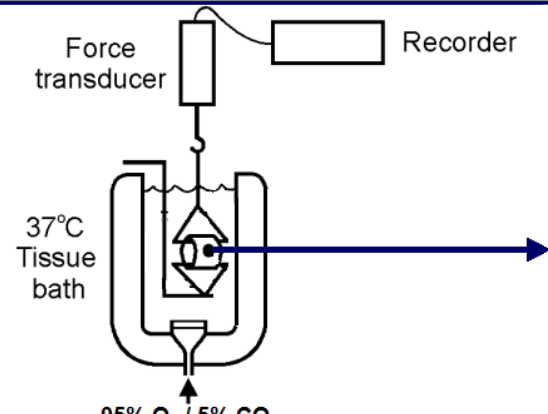

$95 \% \mathrm{O}_{2} / 5 \% \mathrm{CO}_{2}$
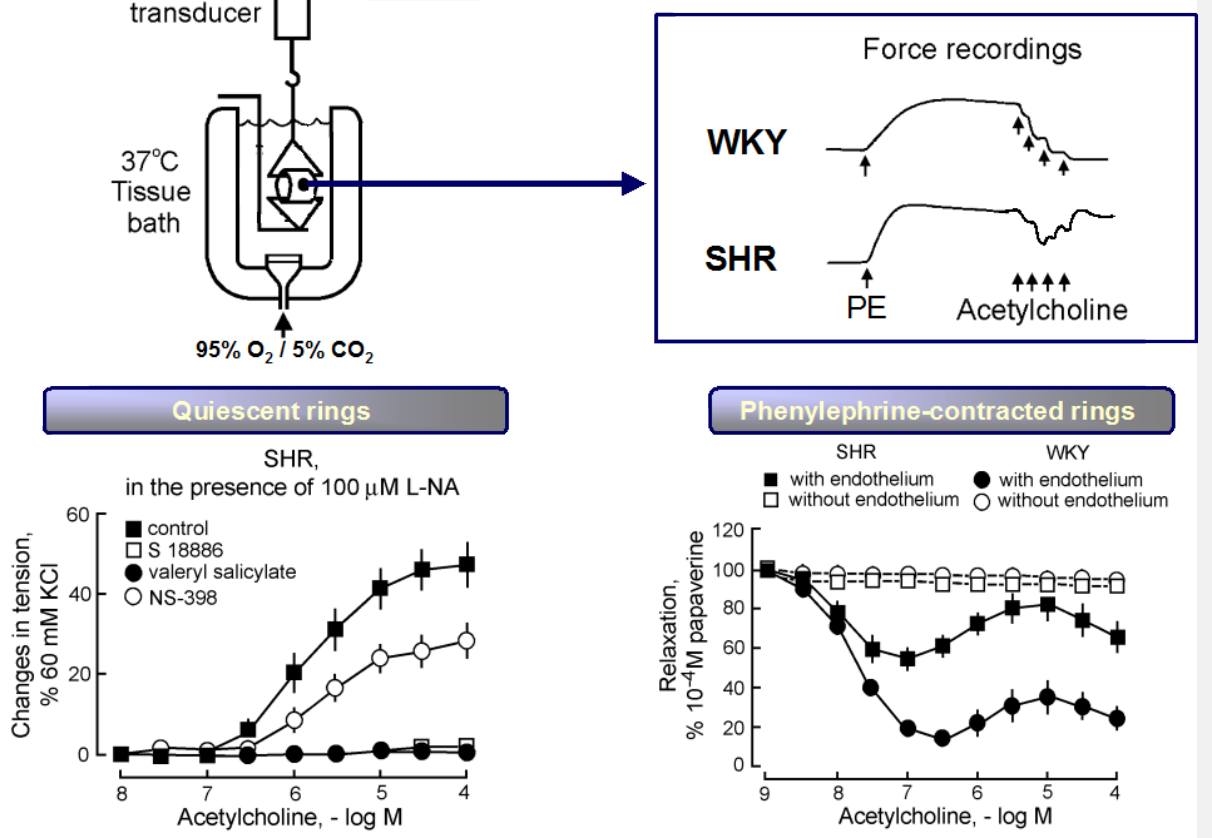


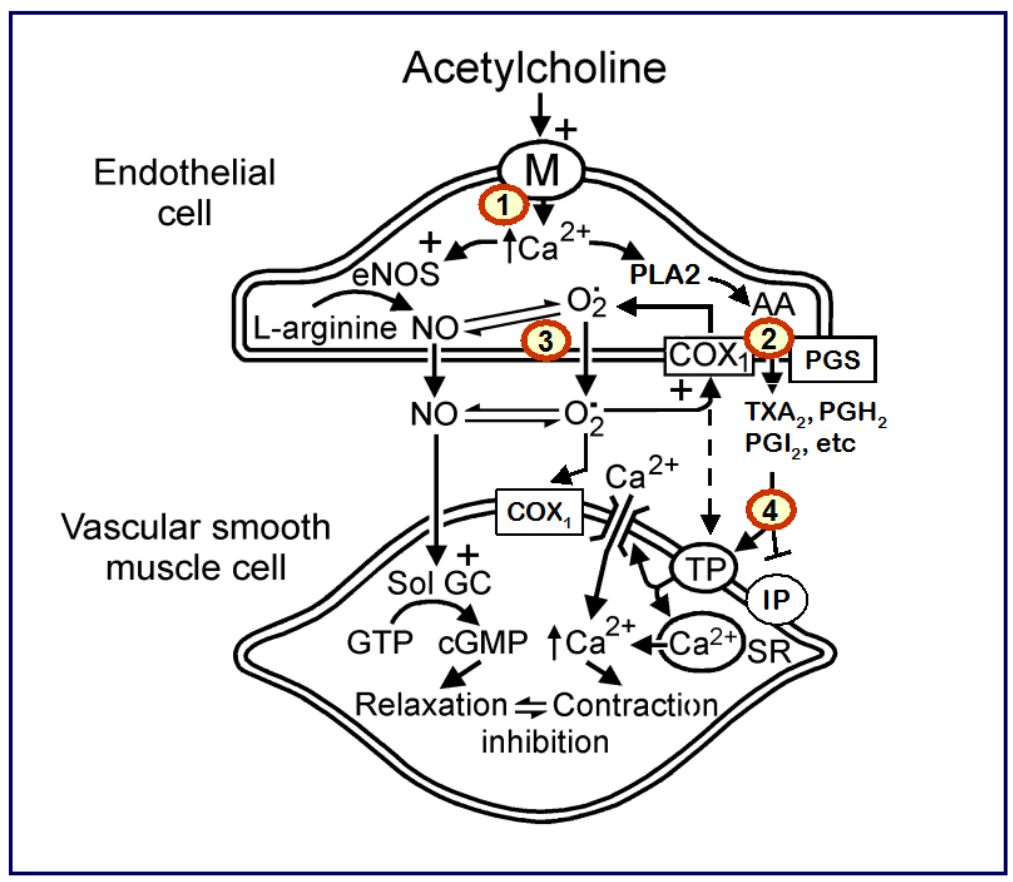


Figure 3

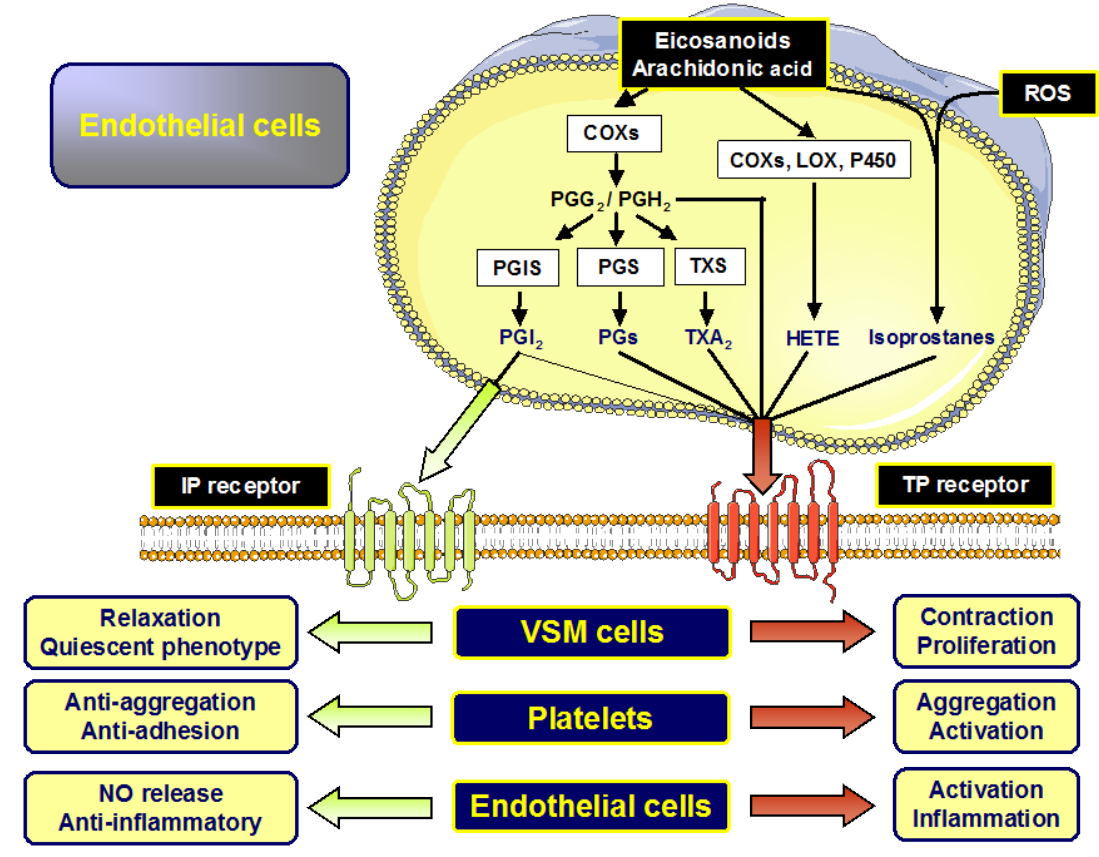

